filologiju, Katedra za srpsku filologiju

jelena.perisic@uj.edu.pl

\title{
NAČINI IMENOVANJA I OBRADE KOLOKACIJA U PRIRUČNICIMA ZA SRPSKI JEZIK KAO STRANI
}

\begin{abstract}
APSTRAKT: Sintagmatska leksička spojivost predstavlja jedan od najvećih problema prilikom usvajanja srpskog kao stranog jezika, posebno kada je reč o kolokacijama spojevima koji se nalaze u kontinuumu između slobodnih spojeva i idioma. Pretpostavlja se da jedan od uzroka može biti i nedovoljna zastupljenost ili nejasna razgraničenost ovakvih konstrukcija u udžbenicima i priručnicima. Stoga, predmet ovog rada jesu kolokacije u priručnicima za srpski kao $\mathrm{J}_{2}$, odnosno načini njihovog imenovanja $\mathrm{i}$ obrade. Cilj istraživanja je utvrđivanje postojećeg stanja u nekoliko priručnika namenjenih nastavi i učenju srpskog jezika na nivoima B1, B2 i C1, kako bi se u daljoj perspektivi unapredila nastava jezika u ovom domenu i pojačala svest polaznika kurseva o kolokacijama kao vidu leksičkih spojeva. Korpus za istraživanje sastoji se od priručnika Naučimo srpski 2, Super srpski i Priručnik za srpski kao strani jezik.
\end{abstract}

Ključne reči: kolokacije, jezička terminologija, nastava jezika, srpski jezik kao strani, jezički priručnici, nivo B1, nivo B2, nivo $\mathrm{C} 1$.

\section{WAYS OF NAMING AND PROCESSING COLLOCATIONS IN COURSEBOOKS OF SERBIAN AS A FOREIGN LANGUAGE}

ABSTRACT: Syntagmatic lexical compatibility is one of the biggest problems in adopting Serbian as a foreign language, especially regarding collocations - compounds in a continuum between free compounds and idioms. It is assumed that difficulties may be caused by insufficient representation or unclear demarcation of such constructions in learning materials and textbooks. Consequently, the subject of this paper is naming and processing collocations in manuals for learning Serbian as $\mathrm{L}_{2}$. Our research aims to determine the current situation in several coursebooks of Serbian as a foreign language at levels B1, B2, and C1, in order to improve language teaching in this domain and increase the course participants' awareness about collocations as a form of lexical compounds. The research corpus consists of the coursebooks Let's learn Serbian 2, Super Serbian, and The Manual for Serbian as a Foreign Language.

Key words: collocations, language terminology, language teaching, coursebooks, Serbian as a foreign language, level B1, level B2, level C1. 


\section{UVOD}

Predmet ovog rada predstavljaju kolokacije u priručnicima za srpski jezik kao strani, odnosno načini njihovog imenovanja i obrade u zadacima u okviru različitih nivoa, lekcija i tematskih celina.

$\mathrm{Na}$ samom početku predstavićemo teorijske postavke i ranija razmatranja problema koji su u neposrednoj vezi sa istraživanjem i čine njegovu polaznu tačku: imenovanje $\mathrm{i}$ definisanje kolokacija, mesto kolokacija u ravni sintagmatskih leksičkih spojeva, značaj usvajanja kolokacija prilikom učenja stranog/drugog jezika i obrada kolokacija u priručnicima za $\mathrm{J}_{2}{ }^{1}$. Nakon toga ćemo formulisati ciljeve i izneti osnovne hipoteze, a zatim opisati i korpus na kojem je vršena analiza. Poslednji (i najvažniji) deo rada čini prikazivanje rezultata sprovedene analize, na osnovu čega ćemo izvesti zaključke i ukratko izneti predloge za poboljšanje kvaliteta nastave srpskog jezika kao stranog u domenu usvajanja kolokacija.

\section{TEORIJSKE POSTAVKE I RANIJA ISPITIVANJA PROBLEMA}

\subsection{Imenovanje $i$ definisanje kolokacija $i$ njihovo mesto među sintagmatskim spojevima}

Kolokacije se, kao poseban tip leksičkih spojeva koji se nalazi na prelazu između slobodnih spojeva i idioma, čak i u stručnoj literaturi različito imenuju. Tako G. Blagus-Bartolec (Blagus-Bartolec 2008) pored naziva kolokacija navodi i ostale koji se mogu susresti, poput: spojevi reči, leksičke skupine, sintagme, izrazi, izričaji, lokacije, idiomi, sveze, višerečnice i slično, a ona sama uvodi termin kolokacijske sveze. Kao što se može primetiti, svaki od naziva nastoji da preciznije približi fenomen kolociranja - povezivanja reči u jednu čvršću strukturu, imajući u vidu njihovu leksičku i gramatičku spojivost. Međutim, većina datih naziva je ili previše uopštena, ili izaziva zabunu i svrstava ih među druge tipove sintagmatskih leksičkih spojeva. Što se same definicije kolokacija tiče, takođe nailazimo na donekle različite uglove posmatranja. Primera radi, Silić i Pranjković (SilićPranjković 2008: 261) kolokacije opisuju kao spojeve reči ili spojeve sintagmema jedinice leksičkog nivoa koje se sastoje od najmanje dve povezane sastavnice ili tagmeme, tj. autosemantične reči ili oblika. Većina leksikologa (Halliday et al.

\footnotetext{
${ }^{1}$ Strani, nematernji, drugi jezik.
} 
1964: 33; Ridout-Waldo-Clarke 1970; Backlund 1973; Seaton 1982; Crystal 1985: 55; Cruse 1986: 40) kolokaciju definiše kao fenomen kod kojeg leksičke jedinice pokazuju tendenciju ka zajedničkom pojavljivanju sa jednom ili više drugih reči. Nejšn (Nation 2013: 317) ih opisuje kao grupu reči koja čini vezanu celinu, bilo zato što se često javljaju zajedno, ili zbog toga što značenje celine nije očigledno na osnovu značenja delova.

Važno je razgraničiti kolokacije od ostalih sintagmatskih leksičkih spojeva - slobodnih spojeva i idioma, što i nije tako jednostavno, budući da postoje i granični slučajevi.

Napravivši sintezu svih ranijih ispitivanja $u$ vezi sa diferenciranjem spomenutih spojeva, J. Dražić (Дражић 2014: 80) izdvaja ključne parametre prema kojima ih je moguće razlikovati ${ }^{2}$. Na osnovu toga daje tabelarni prikaz koji se može opisati na sledeći način: Slobodni spojevi predstavljaju zbir leksema primarnog značenja, kolokacioni opseg im je širok, stepen zamenljivosti visok, a postojanost niska. Otvorene i ograničene kolokacije jesu zbir sekundarnog i primarnog značenja, kod prvih je kolokacioni opseg uži, a kod drugih uzak, stepen zamenljivosti može se okarakterisati kao slabiji ili slab, postojanost je visoka. Vezane kolokacije su zbir leksema primarnog značenja, sa veoma uskim kolokacionim opsegom i vrlo malim, odnosno nultim stepenom zamenljivosti, a postojanost im je veoma visoka. Idiomi su semantičke transformacije na nivou rečenice (fraze), kod njih ne postoji mogućnost kolociranja i zamene, a postojanost je apsolutna.

\subsection{Značaj izučavanja kolokacija u okviru $J_{2}$}

U poslednje vreme kolokacije postaju predmet istraživanja sve većeg broja stručnjaka koji se bave primenjenom lingvistikom i kolokacijama u pedagoškoj praksi. Posebna pažnja poklonjena je ispitivanju principa usvajanja kolokacija prilikom učenja stranog jezika, pretežno engleskog. U ovom domenu izdvaja se rad Majkla Luisa (Lewis 1993; 2000), čije se ideje mogu svesti na postavljanje gramatike u drugi plan i razumevanje jezika putem leksičkih celina (engl. lexical chunks), s obzirom na to da se jezik ne sastoji od tradicionalne gramatike i viđenja vokabulara, već od spojeva reči kao ustaljenih celina. Luis takođe tvrdi da značajnu

\footnotetext{
${ }^{2}$ Reč je o sledećim parametrima: 1) ostvarena semantička realizacija polisemantičnih reči i moguća semantička transformacija jednog od konstituenata kolokacije; 2) kolokacioni opseg jednog od članova kolokacije; 3) sadržajno i formalno jedinstvena veza, stabilna i bliska terminu.
} 
ulogu u učenju jezika ima upravo sposobnost reprodukovanja čitavih leksičkih sklopova, te bi baš oni trebalo da budu jezički materijal na osnovu kojeg se uočavaju gramatički šabloni. S tim u vezi je i Nejšn (Nation 2013) utvrdio kako većina učenika nije u stanju da uspostavi odgovarajuće veze između oblika i značenja kolokacija u $\mathrm{J}_{2}$. Neda Borić (Borić 2004: 63-66) kolokacijsku kompetenciju opisuje kao ideal kojem treba težiti prilikom usvajanja leksičkog sistema stranog jezika. Autorka ističe kako, prema određenim istraživanjima, čak i do $70 \%$ govornog materijala čini neka vrsta vezanih izraza (engl. fixed expressions). Značaj kolokacija kao lingvističkog područja koje igra važnu ulogu u učenju stranog jezika naglašavaju i H. Burić i J. Lasić (Burić-Lasić 2012: 235236). Kao važan uslov javljanja kolokacija u jeziku posebno ističu učestalost, odnosno pojavljivanje određenih reči u uvek istoj kombinaciji, tako da kasnije u svesti učenika ostaju mimetički zalepljene zajedno. To znači da proizilaze iz učestalosti pojavljivanja, ali na neki način i iz frazeologiranosti, pa ih je onima koji uče jezik ponekad teško razgraničiti od idioma. Prema njihovom mišljenju, može se reći da je neko do kraja savladao jedan strani jezik tek onda kada savlada i njegovu frazeologiju kao jezičku pojavu koja ne izvire samo iz gramatičke, sintaksičke ili semantičke i čisto jezičke logike, već predstavlja sociolingvističku, istorijsku, kulturnu, tradicijsku, i na kraju metaforičku i kreativnu dimenziju određenog jezika. ${ }^{3}$ Isto se tako može reći i za kolokacije jer će gramatički korektna rečenica ipak zvučati pogrešno ako u njoj nije upotrebljena ispravna kolokacija.

Vasiljev i saradnice (Vassiljev et al. 2015: 299), sumirajući ranije zaključke u vezi sa ulogom poznavanja kolokacija u nastavi engleskog jezika kao stranog, navode niz argumenata koji opravdavaju uključivanje kolokacija $\mathrm{u}$ nastavne materijale: 1) poznavanje kolokacija predstavlja esencijalni element poznavanja jednog jezika, budući da su jezičko znanje i njegova upotreba bazirani na asocijacijama između sekvencijalno posmatranih jezičkih jedinica; 2) fluentna upotreba jezika zahteva kolokacijsko znanje, s obzirom na to da se autentični tekstovi u velikoj meri sastoje od ovakvog jezika; 3) upotreba kolokacija odslikava neproizvoljnu prirodu i predvidljivo oblikovanje leksikona; 4) poznavanje kolokacija učeniku olakšava proces razmišljanja, memorisanja i iznošenja kompleksnih ideja.

\footnotetext{
${ }^{3}$ Ovo se poklapa sa definicijom Jasmine Dražić, prema kojoj je kolokacija: „sintagmatski leksički spoj dveju ili više autosemantičnih leksema, ustrojen prema morfosintaksičkim pravilima datog jezika, s većim ili manjim stepenom postojanosti i međusobne vezanosti elemenata, uslovljenim jezičkim, vanjezičkim, kulturno-istorijskim i društvenim datostima" (Дражић 2014: 73).
} 


\subsection{Obrada kolokacija u priručnicima za $J_{2}$}

Tumer i Elgort (Toomer-Elgort 2019) smatraju da problemi u recepciji i produkciji kolokacija nastaju delimično i zbog manjka efikasnih nastavnih aktivnosti, zadataka i uputstava u zadacima. Napominju da je neophodno sprovesti opsežna istraživanja kako bi se osvetlili različiti aspekti prirode i kompozitne strukture leksičkih i gramatičkih kolokacija, a onda kreirale najbolje instrukcije u zadacima, kao i nastavni materijali koji bi poboljšali kompetencije studenata $\mathrm{J}_{2} \mathrm{u}$ ovom domenu. Prema M. Bergovec (Bergovec 2007: 58), koja je zagovornik leksičkog pristupa, poželjno je da lekseme i leksički spojevi budu uvedeni kao deo situacije, odnosno konteksta u kojem se i inače nalaze. ${ }^{4} \mathrm{Na}$ taj način se brže prepoznaju, usvajaju i na kraju efikasnije koriste u različitim govornim situacijama, pa učenike treba izložiti velikoj količini pisanog i govornog materijala. Trebalo bi ih, takođe, naučiti samostalnom i sistematskom beleženju korisnih izraza i rečenica, kolokacija, frazema, itd. Jedna od ideja koju autorka iznosi jeste da se izrazi i rečenice sličnog sintaksičkog modela mogu kasnije grupisati u kolokacijske tabele. Malmir i Parhizkari (Malmir-Parhizkari 2021) su ispitivali efekat koji zadaci kao što su definisanje, popunjavanje praznina i pisanje rečenica (u kojima će se naći zadati spojevi) imaju na usvajanje kolokacija. Rezultati su pokazali da studenti kod kojih su primenjivane vežbe sastavljanja rečenica pokazuju bolje kompetencije $^{5}$ u pogledu leksičkih kolokacija od onih kojima su date vežbe sa definicijama na $\mathbf{J}_{2}$ ili vežbe sa popunjavanjem praznina. Osim toga, popunjavanje

\footnotetext{
${ }^{4}$ Autorka dodaje i to da:

„, (...) izvankontekstne gramatičke vježbe trebalo bi u leksičkom pristupu izbjegavati, ili barem smanjiti jer od njih nema komunikacijske koristi. U nastavi stranoga jezika vođenoj načelima leksičkoga pristupa potrebno je poučavati stvarni i mogući jezik. Pri tome se misli na lekseme i leksičke sklopove za koje postoji vjerojatnost da će ih učenik u svakodnevoj komunikaciji čuti (u cjelosti ili samo dio) i moći ponovno upotrijebiti" (Bergovec 2007: $58)$.

${ }^{5}$ Ovo se može potkrepiti i tvrdnjom Laufer (Laufer 1997) koja smatra da se vežbama sa osmišljavanjem i pisanjem rečenica mogu postići impresivni rezultati u pogledu memorisanja reči. Dok koriste leksičke ili gramatičke kolokacije u iskazima, učenici treba da zapaze reč i pokušaju da pretpostave kako se ona može upotrebiti u rečenici, povezana sa drugim rečima. Stoga, učenicima $\mathrm{J}_{2}$ trebaju semantička i sintaksička znanja, poznavanja gramatičkih pravila, pa i pragmatička znanja o tome kako na prikladan način upotrebiti određenu kolokaciju u rečenici. Osim toga, kako tvrde Malmir i Parhizkari (MalmirParhizkari 2021: 71), pisanje pomaže učenicima da uvežbavaju reč i sačuvaju je u dugotrajnoj memoriji. Dok pišu, oni aktiviraju svoje kognitivne funkcije višeg stepena, što predstavlja osnovu za stabilno i obimno učenje.
} 
praznina se pokazalo kao efikasniji način učenja, prisećanja i pamćenja i leksičkih i gramatičkih kolokacija nego što je to slučaj sa povezivanjem spoja sa definicijom na $\mathbf{J}_{2}{ }^{6}$

\section{POTREBA ZA ISTRAŽIVANJEM, CILJEVI I HIPOTEZE}

Prethodno opisani problemi ukazuju na potrebu za analizom nastavnih materijala koji se koriste u nastavi srpskog kao stranog, budući da i iskustvo u radu sa studentima na različitim nivoima učenja jezika otkriva kako se najveći broj teškoća javlja upravo u recepciji i produkciji sintagmatskih leksičkih spojeva. ${ }^{7}$ Cilj istraživanja jeste utvrđivanje postojećeg stanja u nekoliko priručnika namenjenih nastavi i učenju srpskog jezika na nivoima B1, B2 i C1, kako bi se u daljoj perspektivi unapredila nastava jezika u ovom domenu i pojačala svest polaznika kurseva o kolokacijama kao vidu leksičkih spojeva.

Pretpostavlja se da u priručnicima postoje vežbe koje aktiviraju receptivne i produktivne sposobnosti u domenu kolokacija, ali je mali broj onih u kojima se kolokacije sistemski uvežbavaju. Takođe, ne očekuje se veliki broj zadataka u kojima se, u okviru uputstva za izradu, kolokacije precizno imenuju i jasno razgraničavaju od ostalih sintagmatskih leksičkih spojeva - slobodnih spojeva i idioma.

\section{ANALIZA I REZULTATI ANALIZE}

\subsection{Opis uzorka}

Korpus za istraživanje čine sledeći udžbenici i priručnici:

1. Naučimo srpski $2^{8}$ (2007) - udžbenik i radna sveska koja ga prati, predviđeni za učenje srpskog jezika kao stranog na nivoima B1 i B2. Oba priručnika sastoje se od po deset lekcija (1-5 za nivo B1, 6-10 za nivo B2).

\footnotetext{
${ }^{6}$ Ovako drastičnu razliku autori objašnjavaju činjenicom da su rečenice u kojima je potrebno popuniti praznine delimično kontekstualizovane i obezbeđuju bolju osnovu za usvajanje kolokacija, dok definicije pružaju samo značenje reči ili leksičkog spoja (Malmir-Parhizkari 2021: 69).

${ }^{7}$ Ispitivanje kolokacijske kompetencije kod poljskih studenata srpskog jezika (Перишић 2020) pokazalo je da se teškoće u prepoznavanju i upotrebi kolokacija javljaju nezavisno od nivoa vladanja jezikom, čak i kod osoba koje su srpski jezik učile više od pet godina.

${ }^{8} \mathrm{U}$ daljem tekstu: NS2.
} 
2. Super $\operatorname{srpski}^{9}$ (2011) - udžbenik namenjen nivoima B2 i C1 (bez jasne granice među nivoima), sastoji se od osam lekcija.

3. Priručnik za srpski kao strani jezik ${ }^{10}$ (2011) - priručnik namenjen svim nivoima izučavanja srpskog jezika kao stranog, od A1 do C2, gde svaki nivo sadrži po osam lekcija. ${ }^{11} \mathrm{U}$ obzir za analizu u ovom radu uzeti su nivoi B1, B2 i C1.

Istraživanjem su obuhvaćeni zadaci u priručnicima, kao i zapisi na marginama. U obzir nisu uzete kolokacije koje se javljaju u tekstovima ${ }^{12}$ predviđenim za usavršavanje veštine čitanja. Takođe, iz analize su izostavljeni zadaci kojima je cilj uvežbavanje deklinacije, konjugacije ili pretvaranje jedne vrste reči u drugu, i u kojima se među ciljanim rečima slučajno našao i poneki konstituent kolokacije.

Tekstovi instrukcija za izradu zadataka posmatrani su sa ciljem utvrđivanja naziva kojima se imenuju kolokacije, ali i načina njihove obrade. Sadržaji zadataka posmatrani su kako bi se utvrdila veza sa temom, smeštanje u kontekst i struktura spojeva.

\subsection{Rezultati istraživanja}

Rezultati su prikazani posebno za svaki priručnik i u okviru njega za svaki nivo $^{13}$, sa kratkim sumarnim osvrtom na kraju. Udžbenik i radna sveska NS2 analizirani su odvojeno, ali su prilikom izvođenja zaključaka posmatrani kao jedna celina.

\subsubsection{NS 2}

\subsubsection{Udžbenik}

NIVO B1 - U lekcijama predviđenim za nivo B1 registrovan je jedan zadatak koji sadrži kolokacije - u trećoj lekciji, namenjenoj opisu osoba. Kolokacije su opisane terminom reč, a obrađene tako što je dat spisak specifičnih prideva kojima se može opisati kosa (gusta, retka, seda, kovrdžava...), nos (prćast, kukast, orlovski) ili uši (klempave).

\footnotetext{
${ }^{9}$ U daljem tekstu: $S S$.

${ }^{10}$ U daljem tekstu: PZSKSJ.

${ }^{11}$ Nakon svih lekcija dodat je i odeljak Gramatičke vežbe, koji nije uzet u obzir prilikom analize, budući da vežbe nisu podeljene po nivoima.

${ }^{12}$ Osim ako nisu kasnije izdvojene iz teksta.

${ }^{13}$ Osim $S S$, gde nema jasno naznačene granice među nivoima.
} 
NIVo B2 - U lekcijama namenjenim za obradu na nivou B2 zabeleženo je sedam zadataka u četiri različite lekcije - 2 u šestoj (gastronomija, zdravlje i bolesti, saveti), $1 \mathrm{u}$ sedmoj (sport i slobodno vreme), 2 u osmoj (posao) i $2 \mathrm{u}$ devetoj (putovanja, čitanje) lekciji. Nazivi navedeni u zadacima sa kolokacijama su: pojam, izraz (2 puta), reč ili izostaje bilo kakvo imenovanje. Što se obrade kolokacija tiče, u jednom od zadataka iz šeste lekcije potrebno je izbaciti uljeze (uz reči: posećivati, omiljeno, naručiti, nacionalni, probati), a kao dodatak date su i lekseme kojima se može opisati vino (belo, crno, crveno, roze), pivo (svetlo, tamno) ili sok (gusti, gazirani, negazirani, od jabuke/kruške...). U drugom zadatku iz ove lekcije u tri kolone su navedeni glagoli (kuvati, peći, mazati, ljuštiti...), vrste hrane (sarma, supa, meso, jogurt, jabuka...) i kvantifikatori (čaša, kašika, komad, flaša, džak...) koje treba međusobno povezati - prvu kolonu sa drugom, drugu sa trećom. U sedmoj lekciji je, uz tekst, sa strane istaknuta lista kolokacija - vršiti pritisak na nekog, posvetiti pažnju nečemu/nekome. U jednoj od vežbi iz osme lekcije potrebno je utvrditi značenja spojeva: dobiti posao, otkaz; imati/dati dobre preporuke i navedene su kolokacije sa leksemama posao, preporuka, oglas, plata, mušterija... Uz jednu od vežbi iz iste lekcije nalazimo spisak kolokacija koje treba iskoristiti u pisanju žalbe: izraziti nezadovoljstvo, žaljenje, stav; uputiti žalbu; izborna procedura; prosečna ocena; štampani radovi; iskustvo u nastavi. U jednom od zadataka iz devete lekcije treba dodati ponuđene reči uz lekseme: soba, noćenje, pansion, a u drugom objasniti spojeve poput: privatni/hotelski smeštaj, bračno putovanje, celodnevni boravak, turistički aranžman.

\subsubsection{Radna sveska}

NIVO B1 - Na nivou B1 kolokacije su prisutne u dva zadatka, po jednom u dve lekcije - trećoj i četvrtoj. Ni u jednom od njih nije naveden naziv za ovakve spojeve. Obrađene su na taj način što je u zadatku u okviru treće lekcije potrebno napisati antonime konstrukcija kao što su npr. ravna/gusta/kratka kosa, krupne oči, debeo čovek, dok se u zadatku iz četvrte lekcije traži od studenata da izbace uljeza, odnosno reč koja se ne može kombinovati sa zadatim, gde se dva primera odnose na kolokacije sa glagolima polagati - vožnju, ispit, radost i obilaziti-grad, vreme, Evropu.

NIVo B2 - Na nivou B2 u pitanju su četiri zadatka u tri lekcije - dva u šestoj (gastronomija, zdravlje i bolesti, saveti), po jedan u sedmoj (sport i slobodno vreme) i devetoj (putovanja, knjige, čitanje) lekciji. Za kolokacije se koriste termini: pojam (6. lekcija), frazeologizmi (9. lekcija) ili izostaje naziv u uputstvu za izradu zadatka (7. lekcija). Kada je u pitanju obrada, u jednom od zadataka iz 6 . 
lekcije potrebno je povezati spojeve tipa: veza luka, kocka šećera i slično, a zatim u okviru sledećeg zadatka napisati rečenice u kojima će se pojaviti prethodno dobijeni spojevi. U zadatku iz sedme lekcije treba povezati imenice i glagole (npr. baviti se veslanjem, ličiti na majku, odmahivati glavom, nadoknaditi čas i sl.). U zadatku iz 9. lekcije, među pravim frazeologizmima u vezi sa knjigama i čitanjem, koje treba povezati sa značenjem, našle su se i kolokacije kao npr. knjiga žalosti.

$\mathrm{Ni}$ u jednom uputstvu za izradu zadatka kolokacija nije nazvana svojim imenom. Korišćena su određenja poput: reč, pojam, izraz, kod jedne vežbe čak i frazeologizam, ili je naziv izostao. Kolokacije su u zadatke uvrštene tematski - u skladu sa tematikom lekcije u kojoj se obrađuju, što omogućava smeštanje u kontekst, lakše memorisanje i kasnije reprodukovanje naučenih kolokacija. Dotaknut je i problem antonimije u kolokacijama, polja koje je veoma značajno kod usvajanja ovih leksičkih jedinica i jako čest izvor grešaka. Liste gramatičkih i leksičkih kolokacija koje se javljaju na marginama uz pojedine tekstove takođe su dobar podsticaj za pamćenje datih konstrukcija i kasniju pravilnu upotrebu. Vežbe u kojima je potrebno povezati kolone ili objasniti značenja u nekoliko slučajeva praćene su zahtevom da se dobijeni spojevi iskoriste u novostvorenim iskazima (pismeno ili usmeno).

\subsubsection{SS}

U ovom priručniku kolokacije su uočene u ukupno devet zadataka u okviru pet lekcija - 2 u prvoj (komunikacija), 1 u drugoj (rodoljublje), 2 u petoj (finansije, uspeh), 3 u šestoj (posao, zaposlenje) i 1 u osmoj (junaci današnjice). Za kolokacije se koristi naziv izraz (2 puta) ili ga uopšte nema - eventualno se navode vrste reči koje će se pojaviti u zadatku (imenice, glagoli). Kada se radi o obradi ovih leksičkih spojeva, u jednom od zadataka iz prve lekcije među primerima za gestove koje treba povezati sa značenjima našle su se i kolokacije: klimati glavom, klatiti nogom, mahati rukom, odmahivati glavom, cupkati nogom. U narednom zadatku iz ove lekcije potrebno je od nekoliko sinonimičnih izabrati odgovarajući glagol koji se uklapa u kontekst - neki primeri su specifične kolokacije (saopštiti rezultate, izložiti mišljenje). U drugoj lekciji javlja se zahtev da se povežu glagoli sa imenicama uz koje se mogu pojaviti. U zadacima iz pete lekcije potrebno je povezati glagole (sklopiti, prekinuti, raskinuti, organizovati, zakazati, potpisati, otkazati) sa odgovarajućim rečima (govor, ugovor, predgovor, razgovor) i tako formirati spojeve, ili podvući odgovarajući glagol - u pitanju su kolokacije sa glagolima dostići, osvojiti, postići, gde se lako može pogrešiti u izboru sinonima. Šesta lekcija sadrži tri zadatka u kojima treba: povezati glagole sa njihovim 
dopunama - dobijaju se kolokacije: odgajati decu, donositi odluke, povlačiti poteze i sl.; dopuniti izraze odgovarajućim glagolom (npr. biti pod stresom, boriti se sa stresom); povezati glagole sa imenicama - dobijaju se kolokacije kao npr. probni test, puno radno vreme, dobiti otkaz, voditi računa, ostaviti utisak. U osmoj lekciji registrovana je vežba sa zahtevom da se povežu lekseme iz dve kolone, tako da se na kraju dobijaju kolokacije poput održati govor, izdati zapovest, dolaziti u obzir, krenuti u kontranapad.

Termin kolokacija nije zabeležen ni u jednom uputstvu. Umesto toga, uglavnom se koristi širokoobuhvatan naziv izraz, imenovane su vrste reči koje će se pojaviti u zadatku ili imenovanje izostaje. Osim toga, često se u istom zadatku javljaju i kolokacije i slobodni spojevi i idiomi, što studentima otežava odvajanje kolokacija od drugih reči i leksičkih spojeva. Primeri kolokacija u vezi su (pretežno) sa tematikom lekcije u kojoj se obrađuju. Većina zadataka odnosi se na povezivanje kolona, definicije, ubacivanje datih leksema na pravo mesto kako bi se dobili ispravni leksički spojevi ili odabir odgovarajućeg kolokata od nekoliko ponuđenih približnog značenja. Ovakvi zadaci nesumnjivo pomažu u otklanjanju problema vezanih za sinonimiju u kolokacijama. Sa druge strane, malo je zadataka koji podrazumevaju produkciju novih iskaza.

\subsubsection{PZSKSJ}

NIVO B1 - U delu posvećenom nivou B1 registrovana su tri zadatka povezana sa kolokacijama - jedan u lekciji Turizam i dva u okviru lekcije Ekologija. Kolokacije su imenovane kao termini ili reči. Što se obrade tiče, u prvom zadatku se iznosi zahtev da studenti opišu turističke atrakcije u svojoj zemlji tako što će koristiti ponuđene reči i izraze - dati su dvočlani spojevi, od kojih većinu čine slobodni spojevi, ali i kolokacije različitog stepena vezanosti, kao npr. vazdušna banja, kulturno i istorijsko nasleđe, zaštićeni objekti, gradska kuća, nadmorska visina, kompleks šuma. U jednom od zadataka u lekciji Ekologija među navedenim terminima koje treba objasniti nalaze se spojevi: kisela kiša, fantomska struja, efekat staklene bašte, alternativna energija, alternativni transport, ekoturizam, dok se u drugom zadatku među ponuđenim rečima koje treba iskoristiti u budućem napisanom tekstu nalaze sledeće: seča šuma, nuklearne probe, klimatske promene.

NIVO B2 - Među zadacima namenjenim nivou B2 usvajanju kolokacija posvećen je jedan zadatak u okviru lekcije Geopolitika. Kolokacije su imenovane kao reči. Obrađuju se tako što se u prvom delu zadatka spajaju pridevski (spoljna, državna, predizborna, politička, vladarska, međunarodna, diplomatska) i imenički 
(misija, organizacija, partija, granica, loza, politika, kampanja) kolokati, a u drugom glagolski (pružati, naslediti, proglasiti, prekršiti, doneti, predložiti, raspisati) i imenički (zakon, podrška, amandman, presto, referendum, nezavisnost, odluka) kolokati.

NIVO C1 - Kod zadataka namenjenih nivou C1 kolokacije su registrovane u jednom zadatku koji pripada lekciji Globalizacija i u uputstvima nisu posebno imenovane. Prvi deo zadatka sadrži reči koje treba ubaciti u tekst - većina leksema je ili deo slobodnog spoja ili se radi o jednoj reči, ali ima i nekoliko konstituenata kolokacija: igrati (ulogu), preuzimati (ulogu), postaviti (pitanje), (prelaziti) granicu. Drugi deo odnosi se na pitanje sa kojim rečima možemo koristiti navedene reči u različitom kontekstu, gde su date reči: prosek, lestvica, nametati, rast, podržavati, a potrebno je svakoj od njih dodati po šest kolokata.

$\mathrm{Ni} \mathrm{u}$ ovom priručniku ne postoji nijedno uputstvo u kojem je upotrebljen naziv kolokacija. Koriste se nazivi reč ili termin, navode klase reči koje su deo zadatka ili izostaje bilo kakav naziv. Uočene su vežbe u kojima je potrebno povezati kolokate ili objasniti značenje kolokacija bliskih terminima. Sporadično se pojavljuju zadaci u kojima je potrebno ponuđene reči ubaciti u tekst, u nekim primerima se dobijaju kolokacije, ali ne sistemski, ni dosledno. Interesantno je to što su jedini zadaci koji aktiviraju produktivne veštine - pisanje i govor uz upotrebu zadatih kolokacija - smešteni na nivo B1, dok ih na B2 nivou nema, a na nivou C1 postoji zahtev da se dopišu kolokati navedenih leksema, što takođe uključuje samostalan rad i razmišljanje o leksičkoj spojivosti.

\section{ZAKLJUČAK}

U Tabeli 1. koja sledi prikazani su sumirani rezultati istraživanja, prema sledećim parametrima: 1) analizirani priručnik, 2) nivo učenja jezika za koji su zadaci predviđeni, 3) u okviru svakog nivoa broj lekcija i zadataka posvećenih usvajanju kolokacija, 4) naziv za kolokacije u uputstvu za izradu i 5) način na koji se ovi spojevi obrađuju (tip vežbe). 


\begin{tabular}{|c|c|c|c|c|}
\hline Priručnik & Nivo & $\begin{array}{c}\text { Broj lekcija / } \\
\text { zadataka }\end{array}$ & $\begin{array}{c}\text { Naziv za } \\
\text { kolokacije }\end{array}$ & Obrada \\
\hline \multirow[b]{2}{*}{$N S 2$} & B1 & $1 / 1$ & reči & - liste reči \\
\hline & B2 & $4 / 7$ & $\begin{array}{l}\text { pojmovi, } \\
\text { izrazi, } \\
\text { reči, } \\
\text { - }\end{array}$ & $\begin{array}{l}\text { - liste reči } \\
\text { - povezivanje kolokata } \\
\text { - izbacivanje uljeza } \\
\text { - izolovani primeri, } \\
\text { objašnjavanje spojeva } \\
\text { - dopisivanje / razvrstavanje } \\
\text { kolokata }\end{array}$ \\
\hline \multirow{2}{*}{$\begin{array}{c}\text { NS2 - radna } \\
\text { sveska }\end{array}$} & B1 & $2 / 2$ & - & $\begin{array}{l}\text { - navođenje antonima } \\
\text { (pridevski kolokati) } \\
\text { - izbacivanje uljeza } \\
\text { - korišćenje zadatih spojeva u } \\
\text { pisanom tekstu }\end{array}$ \\
\hline & B2 & $3 / 3$ & $\begin{array}{l}\text { pojmovi, } \\
\text { frazeologizmi, } \\
\text { - }\end{array}$ & $\begin{array}{l}\text { - povezivanje kolokata } \\
\text { - objašnjavanje spojeva } \\
\text { - korišćenje zadatih spojeva u } \\
\text { pisanju (rečenicama) }\end{array}$ \\
\hline$S S$ & $\mathrm{~B} 2, \mathrm{C} 1$ & $5 / 9$ & $\begin{array}{l}\text { imenice, } \\
\text { glagoli, } \\
\text { izrazi, } \\
\text { - }\end{array}$ & $\begin{array}{l}\text { - izolovani primeri, } \\
\text { povezivanje sa značenjima } \\
\text { - biranje odgovarajućeg } \\
\text { (glagolskog) kolokata } \\
\text { - povezivanje kolokata } \\
\text { - podvlačenje odgovarajućeg } \\
\text { kolokata } \\
\text { - dopunjavanje spoja } \\
\text { kolokatom koji nedostaje }\end{array}$ \\
\hline \multirow{3}{*}{ PZSKSJ } & B1 & $2 / 3$ & $\begin{array}{l}\text { termini, } \\
\text { reči }\end{array}$ & $\begin{array}{l}\text { - objašnjavanje spojeva } \\
\text { - korišćenje zadatih spojeva u } \\
\text { kontekstu (pisanom tekstu i } \\
\text { usmenom izlaganju) }\end{array}$ \\
\hline & B2 & $1 / 1$ & $\begin{array}{l}\text { reči, } \\
-\end{array}$ & $\begin{array}{l}\text { - povezivanje kolokata - } \\
\text { imenice i pridevi, glagoli i } \\
\text { imenice }\end{array}$ \\
\hline & $\mathrm{C} 1$ & $1 / 1$ & - & $\begin{array}{l}\text { - ubacivanje leksema (među } \\
\text { kojima su i konstituenti } \\
\text { kolokacija) u tekst } \\
\text { - dopisivanje kolokata }\end{array}$ \\
\hline
\end{tabular}

Tabela 1. Imenovanje i obrada kolokacija u posmatranim priručnicima 
Ukupno je registrovano dvadeset sedam zadataka koji se odnose na kolokacije (komplet $N S 2-13, S S-9, P Z S K S J-5$ ). Zabrinjava činjenica da se ni u jednom uputstvu za izradu, čak ni u jednom priručniku, ne pojavljuje termin kolokacija. Nazivi koji su registrovani u instrukcijama su: reč $(4 \mathrm{x})$, pojam $(2 \mathrm{x})$, izraz (2x), frazeologizam, termin, javljaju se nazivi vrsta reči kao što su imenice ili glagoli, a nije mali ni broj zadataka u kojim bilo kakav naziv u uputstvu izostaje ${ }^{14}$. Jedan od razloga zašto uputstva treba da sadrže termin kolokacija jeste taj što se navedeni priručnici, između ostalog, koriste i na stranim univerzitetima na lektorskim vežbama sa studentima (srpske) filologije. Stoga bi za jednog budućeg filologa bilo veoma dobro da postepeno uvodi lingvističke termine jezika koji uči/studira, kao i da prepoznaje razliku među različitim tipovima leksičkih spojeva.

Retki su i zadaci u kojima se sistemski uvežbavaju kolokacije. Pretežno se radi o vežbama gde postoje i drugi sintagmatski leksički spojevi, što studentima ne daje signal da postoji razlika između kolokacija i slobodnih spojeva sa jedne, i kolokacija i idioma sa druge strane. U ovakvim slučajevima može pomoći lektor tako što će ukazati studentima da između tih spojeva postoje razlike i podsticati ih da sami razdvoje kolokacije od ostalih sintagmi ili izraza i definišu njihove osobine.

Uočeno je da su u svim priručnicima primeri kolokacija u vezi sa tematskom celinom koja se obrađuje, što studentima omogućava lakše smeštanje primera u kontekst i mentalni leksikon.

U pogledu strukture, najviše je primera kolokacija koje su kombinacija glagola $\mathrm{i}$ imenice ili imenice $\mathrm{i}$ prideva. Uočeni su i primeri gde imenica $u$ nominativu kolocira sa imenicom u genitivu ili (vrlo retko) nekom drugom padežu.

Što se tipova zadataka tiče, zastupljeni su sledeći zadaci: povezivanje kolokata, izbacivanje neodgovarajućih ili izbor odgovarajućih kolokata u nizu od nekoliko ponuđenih, liste reči (izdvojenih iz tekstova), definisanje značenja spojeva ili povezivanje spojeva sa značenjem, dopisivanje kolokata, razvrstavanje kolokata, ubacivanje zadatih kolokata na pravo mesto u tekstu. Jako je važno i ohrabrujuće to što se u nekoliko zadataka pojavljuju vežbe u kojima je potrebno upotrebiti zadate kolokate u rečenicama, tekstu ili usmenom izlaganju (NS2, PZSKSJ). Ipak, takvih primera je samo nekoliko. Spojevi izdvojeni iz teksta takođe su primer dobre prakse, a naredni korak mogao bi biti sastavljanje mini-rečnika

\footnotetext{
${ }^{14}$ Uputstvo glasi, na primer: Povežite kolone, Izbacite uljeze i slično.
} 
kolokacija ${ }^{15}$ (i idioma, ali jasno naznačeno i odvojeno) na kraju svake lekcije ili na kraju udžbenika. Drugi, verovatno i efikasniji, način jeste da takve liste studenti sastavljaju sami, uz konsultacije sa lektorom. Vežbe sa višestrukim izborom, povezivanjem kolokata ili definisanjem značenja predstavljaju dobru osnovu na kojoj lektor može dalje izgraditi i proširiti zadatak - zahtevom da student smisli primer u kojem će date kolokacije upotrebiti u kontekstu, pitanjem može li se umesto jednog od kolokata upotrebiti neki sinonim, objašnjenjem u slučajevima kada ne može i stvaranjem svesti o tome da su kolokacije u manjoj ili većoj meri ograničene u smislu kombinovanja, kao i stalnim ispravljanjem grešaka jer se poslovica „Na greškama se uči” i prilikom usvajanja stranog jezika pokazuje kao relevantna.

\section{LITERATURA}

Alanović, M., Bjelaković, I., Bugarski, N., Dražić, J., Kurešević, M., Vojnović, J. (2007). Naučimo srpski 2. Novi Sad: Odsek za srpski jezik i lingvistiku, Centar za srpski jezik kao strani.

Alanović, M., Bjelaković, I., Bugarski, N., Dražić, J., Kurešević, M., Vojnović, J. (2006). Naučimo srpski 2 - radna sveska. Novi Sad: Odsek za srpski jezik i lingvistiku, Centar za srpski jezik kao strani.

Babić, B. (2011). Naučimo srpski 1 i 2 - rečnik glagola. Novi Sad: Filozofski fakultet.

Backlund, U. (1973). The collocation of adverbs of degree in English - Doctoral Dissertation. Uppsala: Uppsala University.

Bergovec, M. (2007). Leksički pristup u nastavi stranih jezika s posebnim osvrtom na hrvatski. Lahor 2/3: 53-66. Pristupljeno 18. 4. 2021. URL: <https://www.academia.edu/18780913/Leksi\%C4\%8Dki_pristup_u_nastav i_stranih_jezika_s_posebnim_osvrtom_na_hrvatski>.

\footnotetext{
${ }^{15}$ Na osnovu kompleta NS1 i NS2 nastali su nacrt za tematski rečnik u okviru monografije Minimalne leksičke i gramatičke strukture u srpskom kao stranom jeziku Jasmine Dražić (2008) i rečnik Naučimo srpski 1 i 2 - rečnik glagola Biljane Babić (2011), u kojima kolokacije čine integralne delove odrednica. U prvom slučaju su označene i jasno razgraničene od idioma, u drugom svrstane u istu kategoriju sa idiomima. Na kraju priručnika PZSKSJ takođe je dat dvojezični srpsko-poljski rečnik, ali pretežno se radi o pojedinačnim leksemama. Uvrštene su samo pojedine kolokacije koje se mogu smatrati terminima, bez jasne naznake.
} 
Blagus-Bartolec, G. (2008). Kolokacijske sveze u hrvatskom jeziku (s posebnim osvrtom na leksikografiju) - doktorska disertacija. Zagreb: Univerzitet $\mathrm{u}$ Zagrebu.

Borić, N. (2004). Kolokacije kao dio leksičkog pristupa u nastavi stranih jezika (s posebnim osvrtom na engleski jezik), u Suvremena kretanja u nastavi stranih jezika, ur. Diana Stolac et al. (Zagreb: Hrvatsko društvo za primijenjenu lingvistiku): 63-68.

Burić, H., Lasić, J. (2012). Kolokacije u nastavi inojezičnoga hrvatskog. Zbornik radova Filozofskog fakulteta u Splitu 5: 233-249.

Cruse, D. A. (1986). Lexical Semantics. Cambridge: Cambridge University Press.

Crystal, D. (1985). A dictionary of linguistics and phonetics. Oxford: Basil Blackwell Ltd.

Dražić, J. (2008). Minimalne leksičke i gramatičke kolokacije u srpskom kao stranom jeziku. Novi Sad: Filozofski fakultet.

Дражић, J. (2014). Лексичке и граматичке колокаиије у српском језику. Нови Сад: Филозофски факултет. [Dražić, J. (2014). Leksičke i gramatičke kolokacije u srpskom jeziku. Novi Sad: Filozofski fakultet].

Halliday, M. A. K., McIntosh, A., Strevens, P. (1964). The linguistic sciences and language teaching. London: Longman.

Laufer, B. (1997). The lexical plight in second language reading: Words you don't know, words you think you know, and words you can't guess. Second language vocabulary acquisition: 20-34. Pristupljeno 18. 4. 2021. URL: <https://www.academia.edu/10234906/The_lexical_plight_in_second_lang uage_reading_words_you_dont_know_words_you_think_you_know_and_ words_you_cant_guess>.

Lewis, M. (1993). The Lexical Approach. London: Language Teaching Publications.

Lewis, M. (2000). Teaching Collocation. Further Developments in the Lexical Approach. Hove, England: Language Teaching Publications.

Liber, K., Prpa, S. (2011). Priručnik za srpski kao strani jezik. Kraków: Wydawnictwo Uniwersytetu Jagiellońskiego.

Malmir, A., Parhizkari, N. (2021). The Effect of Definition, Fill-in-the-Blank, and Sentence Writing Exercises on the Acquisition, Retention, and Production of Lexical vs. Grammatical Collocations. Journal of Teaching Language $\begin{array}{llllll}\text { Skills } \quad 40 & \text { (1): } \quad 33-82 . & \text { Pristupljeno 17. } 4 . & 2021 .\end{array}$ URL:<https://www.academia.edu/45187565/The_Effect_of_Definition_ 
Fill_in_the_Blank_and_Sentence_Writing_Exercises_on_the_Acquisition_ Retention_and_Production_of_Lexical_vs_Grammatical_Collocations>.

Milićević Dobromirov, N., Novković, B. (2011). Super srpski. Novi Sad: Azbukum.

Nation, I. S. P. (2013). Learning Vocabulary In Another Language. Cambridge: Cambridge University Press.

Перишић, J. (2020). Колико Пољаци разумеју српске колокације? (Да ли једном учеснику библиотеке из часа на час пада на мозак да лови и граби белешке?), у Српски као страни језик у теорији и пракси 4: тематски зборник радова, ур. В. Крајишник (Београд: Филолошки факултет): 563-579. [Perišić, J. (2020). Koliko Poljaci razumeju srpske kolokacije? (Da li jednom učesniku biblioteke iz časa na čas pada na mozak da lovi i grabi beleške?), u Srpski kao strani jezik u teoriji i praksi 4: tematski zbornik radova, ur. V. Krajišnik (Beograd: Filološki fakultet): 563-579].

Ridout, R., Waldo-Clarke, D. (1970). A reference book of English. London: Macmillan.

Seaton, B. (1982). A handbook of English language teaching terms and practice. London: The Macmillan Press Ltd.

Silić, J., Pranjković, I. (2008). Gramatika hrvatskoga jezika za gimnazije i visoka učilišta. Zagreb: Školska knjiga.

Toomer, M., Elgort, I. (2019). The development of implicit and explicit knowledge of collocations: A conceptual replication and extension of Sonbul and Schmitt (2013). Language Learning 69 (2): 405-439. Pristupljeno 18. 4. 2021. URL: <The Development of Implicit and Explicit Knowledge of Collocations: A Conceptual Replication and Extension of Sonbul and Schmitt (2013) - Toomer - 2019 - Language Learning - Wiley Online Library>.

Vassiljev, L., Skopinskaja, L., Liiv, S. (2015). The treatment of lexical collocations in EFL coursebooks in the Estonian secondary school context. Eesti Rakenduslingvistika Ühingu aastaraamat 11: 287-311. 
Jelena R. Perišić

Jagiellonian University in Cracow

Faculty of Philology

Institute of Slavonic Studies

\section{WAYS OF NAMING AND PROCESSING COLLOCATIONS IN COURSEBOOKS OF SERBIAN AS A FOREIGN LANGUAGE}

\section{Summary}

While learning any foreign language, including Serbian, students encounter problems in the field of syntagmatic lexical compatibility. Perhaps the most difficulties in this domain are created by collocations - compounds in a continuum between free compounds and idioms. It was assumed that the problems mentioned above might be caused by insufficient representation or unclear demarcation of such constructions in learning materials and textbooks. Consequently, the subject of this paper was naming and processing collocations in manuals for learning Serbian. The research aimed to determine the current situation in several coursebooks for Serbian as a foreign language at levels B1, $\mathrm{B} 2$, and $\mathrm{C} 1$, toward further language teaching improving in this domain and increasing the course participants' awareness about collocation as a form of lexical compounds. The research corpus consisted of the coursebooks Let's learn Serbian 2, Super Serbian, and The Manual for Serbian as a Foreign Language.

After analysing the instructions and content of the tasks, the results revealed that the term collocation does not appear in any coursebook instruction. Additionally, tasks that systematically practice collocations are rare and collocations are not clearly distinguished from idioms and free compounds. Examples of collocations are related to the thematic units - it allows students to memorise and use them efficiently in communication. We registered the following types of tasks: linking the collocates, removing inappropriate or selecting appropriate collocates, definitions or connecting compounds with definitions, adding parts of collocation, sorting collocation, filling in the blanks. There are also tasks where students have to make sentences using the given collocation - this is good for productive competence, but there should be more exercises of this type.

Key words: collocations, language terminology, language teaching, coursebooks, Serbian as a foreign language, level B1, level B2, level C1.

Primljeno: 1. 5. 2021.

Prihvaćeno: 13. 7. 2021. 